\title{
Tillich's Indebtedness to Kant: Two Recently Translated Review Essays on Rudolf Otto's Idea of the Holy
}

\author{
Chris L. Firestone
}

\begin{abstract}
The article will show, through two of Tillich's lesser-known writings the newspaper review articles on the person and work of Rudolf Otto that Otto greatly influenced Tillich at a formative stage in his intellectual development and that several key elements of Tillich's mature thought are found in Tillich's analysis of Otto. It will also show, in reference to the interpretations of Caird and Palmquist, that Otto's philosophy of religion can be fruitfully understood as a direct extension of Kant's critical philosophy. Furthermore, o author show how the superstructure of Tillich's theology bears a striking resemblance to Kant's philosophy in the sense of Caird, Otto, and Palmquist. Insofar as this analysis is accurate, Tillich's systematic theology is as much grounded on the philosophy of Kant as it is on the philosophy of Schelling.
\end{abstract}

Keywords: Tillich, Kant, Otto, Holy

\section{O QUE TILLICH DEVE A KANT: DOIS ENSAIOS BIBLIOGRÁFICOS RECÉM-TRADUZIDOS A RESPEITO DA IDEIA DO SAGRADO DE RUDOLF OTTO}

\section{RESUMO}

$\mathrm{O}$ artigo pretende mostrar, por meio de dois dos escritos mais conhecidos de Tillich - as resenhas em journal sobre a pessoa e a obra de Rudolf Otto - que Otto influenciou grandemente Tillich num estágio formativo do seu desenvolvimento intelectual e que vários elementos-chave do pensamento maduro de Tillich se encontram na análise tillichiana de Otto. Ele quer mostrar também, com referência às interpretações de Caird e Palmquist, que a filosofia da religião de Otto pode ser adequadamente compreendida como extensão direta da filosofia crítica de Kant. Além disso, o autor mostra como a superestrutura da teologia de Tillich carrega 
uma estrita semelhança com a filosofia de Kant no sentido de Caird, Otto e Palmquist. Na medida em que esta análise é correta, a teologia sistemática de Tillich se fundamenta muito mais na filosofia de Kant que na filosofia de Schelling.

Palavras-chave: Tillich, Kant, Otto, Sagrado

\section{Introduction}

A common way of approaching the theology of Paul Tillich is to show its relationship to and reliance on the philosophy of Friedrich W. J. Schelling. It is common knowledge, for instance, that Tillich attributed his theological awakening to his first encounter with the writings of Schelling in a bookstore as a university student and that Schelling's work provided a model for how philosophy and theology could be synthesized and fruitfully employed to meet the conceptual challenges of the $20^{\text {th }}$ century. In reference to his early struggles with the doctrine of justification and the inadequacy of strong-handed applications of orthodoxy for overcoming them, Tillich writes, "It was the work of Schelling, particularly his late thought, which helped me relate these basic theological ideas to my philosophical development. Schelling's philosophical ideas opened the way, I thought, to an unification of philosophy and theology."1 Tillich, of course, goes on to write two Ph.D. dissertations on Schelling's philosophical theology and apply many of Schelling's ideas in his subsequent writings. ${ }^{2}$ No doubt Schelling's work served as the backdrop for many of Tillich's most influential insights.

1 Paul Tillich, On the Boundary: An Autobiographical Sketch (New York: Charles Scribner's Sons, 1966), 51.

2 The first of Tillich's two doctoral dissertations on Schelling was presented for the degree of philosophy at the University of Breslau and the second was presented for the degree of theology at Halle. These were translated into English as Paul Tillich, Mysticism and Guilt Consciousness in Schelling's Philosophical Development, tr. Victor Nuovo (Lewisburg: Bucknell University Press, and London: Associated University Presses, 1974); and Paul Tillich, The Construction of the History of Religion in Schelling's Positive Philosophy: Its Presuppositions and Principles, tr. Victor Nuovo (Lewisburg: Bucknell University Press, and London: Associated University Presses, 1974). These works will henceforth be referred to as Schelling's Philosophical Development and Schelling's Positive Philosophy, respectively. 
In this essay, I want to present the case for another way of approaching Tillich's early intellectual development and its relationship to Tillich's mature systematic theology. My claim is that Schelling was not the only "late-Enlightenment" influence of what I will call "constitutive significance" to Tillich's thought. The philosophy of Immanuel Kant was, I contend, just as influential, perhaps more so. "In my student years," Tillich writes, "there was a slogan often repeated: Understanding Kant means transcending Kant. We all try to do this." ${ }^{\text {" In }}$ Tillich's earliest work on Schelling, the influence of Kant's philosophy on his student years is undeniable. Victor Nuovo, in summing up this influence in his "Introduction" to the English translation of the first dissertation, writes, “Tillich's [Ph.D.] dissertations may be viewed as attempts, through Schellingian concepts, to overcome the Kantian antithesis of historical faith and moral religion, and to provide a metaphysical basis for Kant's doctrine of radical evil and the selfestrangement of the autonomous moral will."

Kant's influence on Tillich was surely profound and foundational, but was it such that it can be what I am calling "constitutive significance" to Tillich's thought in the way Schelling's is accepted to be? In other words, did Kant's philosophy help form some of Tillich's basic concepts and bring shape to the overall structure of Tillich's thought? My answer to both of these questions is "Yes." Yet, there is a sense in which this answer might rightly be viewed as something of a truism or non-falsifiable thesis. One of the distinguishing features of the German Idealists generally is that they all saw themselves as the true heirs of the best of Kant. They were all in one way or another responding to problems left in the wake of Kant and they relied on Kant's writings for intellectual resources for help in resolving them. In other words, it is not all that surprising nor is it all that risky to suggest that Tillich's work is likewise reliant on and responsive to Kant's philosophy. If that were my only argument, I would not be saying all that much. No "constitutive significance" would thereby be shown.

\footnotetext{
3 Paul Tillich, Perspectives on 19th and 20th Century Protestant Theology (London: SCM Press, 1967), 70.

4 Tillich, Schelling's Philosophical Development, 13.
} 
The argument I want to sketch out and defend in brief, however, is a little more sophisticated than this and I think does point to the constitutive significance of Kant's philosophy for Tillich's theology. My claims center on another scholar whose work Tillich often writes about with a tone and frequency very similar to that of Schelling, but who often times gets "the short end of the stick" when it comes to aca- demic recognition and study. The person I have in mind, of course, is the philosopher of religion Rudolf Otto. In the "Autobiographical Reflections," Tillich writes, "When I first read Rudolf Otto's Idea of the Holy, I understood it immediately in the light of these early experiences, and took it into my thinking as a constitutive element. It determined my method in the philosophy of religion, wherein I started with the experiences of the holy and advanced to the idea of God and not the reverse way." 5

This is not the only place where Tillich makes such references to the constitutive significance of Otto's work. We find similar statements in the Systematic Theology and in two review articles Tillich wrote for German newspapers in the 1920's. ${ }^{6}$ The review essays, entitled "The Category of the Holy in Rudolf Otto" (1923) and "Rudolf OttoPhilosopher of Religion" (1925), ${ }^{7}$ make up the lion's share of the evidence that I will forward in support of my thesis. Tillich's consistent testimony, from the 1920 s through to the 1960 s, is thus pro-Otto and not just in a generic sense, but in the sense of Otto's work being "a constitutive element" and what "determined [Tillich's] method."

5 Paul Tillich, "Autobiographical Reflections," The Theology of Paul Tillich, eds. Charles W. Kegley \& Robert W. Bretall (New York: The Macmillan Company, 1952), 6.

6 See, for example, Paul Tillich, Systematic Theology, vol. 1 (Chicago: The University of Chicago Press, 1951), 215-6.

7 Paul Tillich's “Die Kategorie des ,Heiligen' bei Rudolf Otto,, originally appeared in Theologische Blätter (vol. 2, 1923, Spalten 11-12). It can also be found in GW XII, Begegnungen: Paul Tillich über sich und andere (Ed. Renate Albrecht (Stuttgart: Evangelisches Verlagswerk, 1971), 184-186). The translation is based solely on the original document in Theologische Blätter. The second article, originally titled "Denker der Zeit: Der Religionsphilosoph Rudolf Otto," was first published in Vossische Zeitung, 1925, Nr. 308. It can now be found in GW XII, Begegnungen: Paul Tillich über sich und andere, ed. Renate Albrecht (Stuttgart: Evangelisches Verlagswerk, 1971), 179-183. The current translation is based solely on the original version in Vossische Zeitung. Nathan Jacobs and I translate these review articles in the Appendices of Chris L. Firestone, Kant and Theology at the Boundaries of Reason (Aldershot: Ashgate Publications, Ltd., forth- coming 2009). 
In my book, Kant and Theology at the Boundaries of Reason, forthcoming from Ashgate in 2009, wherein these two translated articles appear in the Appendices, I argue that Otto's philosophy of religion can be understood as good example of the religious interpretation of Kant's philosophy. Stephen R. Palmquist, whose work I will examine in more detail below, presents the religious interpretation of Kant's philosophy in his books Kant's System of Perspectives (1993) and Kant's Critical Religion (2000). ${ }^{8}$ To the extent that (1) the groundwork for Tillich's theology can be shown to emerge in response to Otto's philosophy of religion, and (2) Otto's philosophy of religion is best understood as an extension of Kant's critical philosophy under the religious interpretation in the sense of Palmquist, then a solid case can be made for a third claim-namely, (3) Tillich's theology is likewise best understood as a theological response to the philosophy of Kant. My argument succinctly is therefore threefold and these three parts mark out the remaining sections of this essay.

\section{Tillich in "the Light" of Otto}

Looking back at Tillich's two newspaper articles on Otto provides not only valuable insights into Tillich's relationship to Otto, but also a striking look at the seeds of thought that would blossom into some of Tillich's best known theological insights of his American period. For thematic reasons, I will focus first on the 1925 essay, "Rudolf Otto-Philosopher of Religion," and then turn to the 1923 essay "The Category of the Holy in Rudolf Otto."

The 1925 essay is the longer of the two and somewhat more sweeping in its review of the person and work of Otto. It begins as follows:

It was an unforgettable event for me, when, in the fall of 1917, Rudolf Otto's book on "The Holy" - a marvelous early draft, sent from a dear woman who had died early — came to me at the camp "Note Erde" on a

8 Stephen R. Palmquist, Kant's System of Perspectives: An Architectonic Interpretation of the Critical Philosophy (Lanham, Maryland: University Press of America, 1993) and Kant's Critical Religion: Volume Two of Kant's System of Perspectives (Aldershot: Ashgate Publications, Ltd., forthcoming 2009). 
high mountain in Champagne. I was taken aback for a moment by several oddities in the writing style and the completely unknown publisher. But then an amazement began, an internal thrill, a passionate approval, in a way one is no longer used to with theological books (RO1). ${ }^{9}$

Tillich goes on in this article to unpack Otto's career and thought, highlighting Otto's relationship to the Neo-Kantians in general and Leonhard Nelson of Göttingen in specific. After marching his way through these highlights, Tillich returns to the significance of Otto's thought for the era:

With this last remark, the intellectual significance of Otto's thoughts is now touched on. They have become for theology a complete breakthrough of the wholly other. They have saved the work on theology and philosophy of religion from the difficulties of the rational problem, from the corruption of logic and ethics. They have created a new foundation on which to build, and on which many of Otto's rivals also build, with or without his knowledge" (RO7).

We see in this passage, and in what follows it, not only Tillich's grand appreciation of Otto's work but also hints regarding its significance and those places in Otto's work requiring further thought and development.

Speaking somewhat poetically of himself, Tillich continues, "But who, like the author of these lines, has experienced the liberation that the book on The Holy has given him; he too can go there, where he believes he must proceed to, like for example in the determination of the relationship of the rational and irrational, of otherworldliness and this-worldliness of the Numinous, in order to not forget the first breakthrough" (RO7). This point was already taken up in earnest in the 1923 essay, which we will get to in a moment, but here serves merely as an honorarium to the career of the great philosopher of religion, his good friend, Rudolf Otto. The article closes with this remark: "Out of

\footnotetext{
9 All citations for "The Category of the Holy in Rudolf Otto" (1923) and "Rudolf OttoPhilosopher of Religion" (1925) are embedded at the end of the text as paragraph numbers- "CH" for the 1923 article and "RO" for the 1925 article. At the time of writing this essay, page proofs (with page numbers) for Kant and Theology at the Boundaries of Reason have not yet been received.
} 
devotion to the capturing of the Numinous, [Otto] devoted work to practical and theoretical Protestant religious reform. But what is decisive and makes him one of the most important figures in contemporary theology, is his book on The Holy, for that an entire generation owes him thanks" (RO9).

By itself, the 1925 article does not present us with direct evidence of Tillich's reliance on the work of Otto, only the clear indication that Tillich read and understood Otto's work in great detail, openly declaring its significance and his adoration for it without qualification. In the other review essay, however, the one devoted specifically to Otto's The Idea of the Holy, Tillich is far more forthcoming about his intellectual indebtedness to Otto's work. There, Tillich calls Otto's text "the breakthrough book in the field of philosophy of religion, but not only a breakthrough, it has also been the guide for philosophy of religion to this day. For those who, like the reviewer, are among the first working in the area, and those whose ideas have been influenced by this impression, it is a duty to give thanks and testify to the book's beauty and power" (CH1). His purpose in this article is not merely to sing Otto's praises, though he does plenty of that; the purpose of the article is, in Tillich's words, "not to say all this" but to identify "at which points of Otto's book must we take up this great work, and how should we build on Otto's achievement" (CH3).

According to Tillich, the subtitle of The Idea of the Holy-namely, On the Non-Rational in the Idea of the Divine and Its Relation to the Rational-is only partially realized in the book. The non-rational is famously and insightfully explored, but how the non-rational is related to the rational was not, in Tillich's estimation, fully determined (CH4). "For this," Tillich tells us, "you need a critical element in the Kantian sense" (CH5). Tillich calls this Kantian critical element "a method of critical-intuition" (CH5). According to Tillich,

Otto himself heads in this direction when he speaks of the religious disposition and makes the Holy into an a priori category. A religious a priori, however, cannot suddenly stand beside the rest of the a priori, not even if its content is the "wholly other." It must be shown in which natural relation this "wholly other" stands to the rest of the forms of 
consciousness. For if it stood nowhere, or even only in an additional relation, then the unity of consciousness would burst (CH5).

Here, we find something more than mere enthusiastic adulation for Otto's work; we find the beginnings of a serious philosophical engagement. Tillich's criticism of Otto can be summarized as follows: Because Otto turns to "the faculty of divination" as a type of fourth realm of reason, Otto in effect amends Kant's critical philosophy by adding to it a fourth a priori standpoint. This standpoint cannot suddenly appear, thinks Tillich, for it has no clear critical grounds in reason, no intellectual precedent in the great work of Kant. So it must either stand nowhere or be an unnatural addition to Kant's critical program. The direction that Tillich maps out to build on Otto's achievement, then, cannot be to understand the faculty of divination as a fourth, independent addition to Kant's critical philosophy, but rather to understand it as something more transcendental and ontological, something related to reason holistically-more formal than technical.

Tillich's response to and reliance on Otto's The Idea of the Holy, however, runs deeper than merely relating the non-rational less technically and more holistically to the rational in a sense amenable to Kant's critical philosophy. Tillich seizes on the insight that Otto "brings to expression...the natural relationship of the Holy... [in] the concept of the un-conditioned" (CH6). As a consequence of reading Otto, it seems, the concept of the unconditioned be- comes, for Tillich, closely tied to the natural human experience of the Holy. Tillich finds this idea to be both a breakthrough and an insight in need of further clarification and development.

Tillich, in pointing out the strengths and weak- nesses of Otto's position, does not merely accept Otto's formulation as it stands. He continues, "It is not proper that Otto declares this concept to be only quantitatively distinct from the conditioned; rather, it contains in itself the entire force of the qualitatively 'other,' the 'unfamiliar'" (CH6). The wholly other, in other words, is not merely some non-descript, mysterious entity that occasionally impinges itself on the religiously sensitive members of the human species. The "unconditioned one," as Tillich designates it in this article, or "Being-itself," as he would later 
call it, "is so important that I cannot avoid it under any circumstances" (CH6). The "wholly other" or the "unconditioned one" lies at the ground of all human experience and, in words of the later Tillich, is the "ultimate concern" of human beings. "Thus," Tillich writes, "the concept of the unconditioned is not, as Otto states, a pattern of rationalization, but an element of the Holy itself" (CH6).

Tillich's analysis of Otto achieves its full force in the integral relationship between the unconditioned one as the source of human experience and human rationality as its essential instrument or conduit. Here, we find the decisive moment in Tillich's engagement with Otto and why I think there is more than mere regulative significance to Tillich's employment of Otto's ideas. Tillich writes, "The unconditioned is not only a posteriori by schematization, but also a priori by natural relationship, which is the foundational element of all value consciousness" (CH6). Because human beings are conscious and willful participants in being as actuality, the unconditioned has a "natural relationship" to the world in and through humanity. Religious experience, as a distinct aspect of human experience in general, is in this sense foundational to all experience-it is, in Tillich's words, both a posteriori and a priori, or, put another way, it is the product of the transcendental nature of reason understood in its phenomenological fullness. ${ }^{10}$

This is why, I think, Tillich understands the unconditioned as something more than the "mystery of Being" in the sense of Otto; it is also, as Tillich goes on to suggest, the "mystery of the Light" (CH6). Tillich explains, "Being comes to itself in the Light. The unconditioned substance and the unconditioned form essentially belong together" (CH6). This climactic moment in the essay bursts with meaning, alluding to the religious potentiality buried deeply within the very rationality that defines human beings (logos) and exemplified ultimately in Jesus as the Christ, the light of the world.

10 Otto's contention that the faculty of divination is sensitive to a "sheer over-surplus" of meaning in human experience is not therefore evidence of rational separation, but instead, in Tillich's way of thinking, evidence for this foundational status. Religious experience speaks of both the outermost limits human experience and the mystery of human consciousness that makes any experience possible in the first place. All these concepts, interestingly enough, are re-confirmed on pages 215 and 216 of the Systematic Theology, vol. 1. 
In sum, we find in Tillich's review of The Idea of the Holy more than just tidbits of his mature work; there is solid meat. We find, first, the "unconditioned," the "unconditioned one," and the "wholly other" as early illusions to the significance of Being-itself; second, we find that the unconditioned is "something so important that I cannot avoid it under any circumstances" and, equally, the reader cannot avoid the important conclusion that this phrase is linked directly to Tillich's later emphasis on humanity's "ultimate concern"; and, third, we find that the unconditioned is not merely the mystery of being in the numinous sense; rather the unconditioned one is located at the well-lit crossroads of the rational and non-rational within human beings. This third point foreshadows the superstructure of Tillich's mature thought, which puts humanity at what Tillich calls the "perspectival center," standing between God and world as the mystery of "Being" turns into the "Light." 11

\section{Palmquist's Religious Interpretation of Kant}

Stephen Palmquist's interpretation of Kant is significant to the Otto-Tillich relationship because of its close affinities with Otto's philosophy of religion and the remarkable way it resembles Tillich's theology. Before we get to these two points in my argument in the closing section of this paper, we first need to understand in more detail the nature of Palmquist's interpretation of Kant. His interpretation is part of a "new wave" in Kant-studies, which argues that Kant's philosophy is more theologically affirmative than has been traditionally supposed. This wave has been gaining momentum over the last 30 years, and, recently, has crested in a spate of new books and journal articles. ${ }^{12}$ This wave continues to be a major factor in the field of Kant-studies today in challenging the standard portrait of Kant as the "all-destroyer" of metaphysics in favor of a portrait of Kant bent on establishing "rational religious faith" at the transcendental boundaries of reason.

${ }^{11}$ Tillich, Systematic Theology, vol. 1, 189.

12 For a detailed account of this new wave, see Kant and the New Philosophy of Religion and the 2007 Special Symposium Edition of Philosophia Christi. 
In Kant and Theology at the Boundaries of Reason, I present three discernable streams of theologically affirmative Kant interpretationthe moral, poetic, and religious. ${ }^{13}$ Palmquist's interpretation provides a good example of "the religious interpretation" of Kant. ${ }^{14}$

Palmquist's interpretation capitalizes on the often-neglected writings surrounding Kant's critical period. These writings include the much-maligned essay "Dreams of a Spirit-Seer" and Kant's posthumous writings known as the Opus Postumum. According to Palmquist, when these writings are taken seriously, they present a fuller, more complete ac- count of Kant's philosophical program and show that theology can build fruitfully on Kant's philosophy. Palmquist's interpretation is traceable to the pioneering work in 1889 of Edward Caird. ${ }^{15}$ For Caird, the most natural reading of Kant is likewise fourfold and holistic. "For the theoretical, the practical and the aesthetic and religious consciousness are not really independent things, or the products of independent faculties, which stand side by side with each other; they are different forms of one conscious life, forms which rise out of each other in a certain order determined by the very nature of the intelligence." ${ }^{16}$ Caird understood Kant's thought to be a coherent and dynamic whole, in which apparent contradictions find their resolution in the development and filling out of ideas, rather than in their relative demise due to logical inconsistency.

Palmquist argues in a similar fashion that Kant's philosophy ought to be considered less technically and more holistically-as a system of three stand- points grounded by one overarching "Transcendental

13 Tillich, of course, is familiar with all three of these streams of Kant interpretation. In Kant and Theology at the Boundaries of Reason, I show how Tillich interacts with the first two streams directly from Kant and Kant's interpreters, and the third stream indirectly through Otto.

14 Palmquist accepts the designation 'the religious interpretation' in the 'Editors' Introduction' to Kant and the New Philosophy of Religion.

15 Caird's two-volume work, entitled The Critical Philosophy of Immanuel Kant (1889), was the first substantial work on Kant in English covering the full extent of Kant's philosophy (including within its parameters Kant's philosophy of religion). Caird's interpretation of Kant's philosophy is divided into four "books." The first three correspond to the three Critiques and the fourth addresses Kant's Religion. Edward Caird, The Critical Philosophy of Immanuel Kant, vols. I and II (Glasgow: James Maclehose \& Sons, 1889).

16 Caird, The Critical Philosophy of Immanuel Kant, 644. 
Perspective." According to Palmquist, one of reason's three finite standpoints is always operative in human experience, but considered as a whole, the overarching transcendental nature of reason delineates its true boundaries and employments. As Palmquist writes, "This overarching 'Transcendental (or 'Copernican') Perspective', which is based on the assumption that the subject imposes certain a priori conditions on the object, defines the systematic context into which all three Critical systems fit." 17

Both Caird and Palmquist contend that Kant's later writings, particularly the writings on religion and the Opus Postumum, bring into sharp relief a fourth dimension of reason. In other words, a fourth realm of human experience - the religious or mystical — arises out of Kant's 'Transcendental Perspective," but is not to be considered separate from it. The Transcendental Perspective functions as the prereflective interface of reason and being at the outer- most frontiers of human experience. This ontologically robust understanding of the fourth realm, on both their readings, becomes vital to the coherence and completion of Kant's philosophy. We have access to God, and thus can speak and think meaningfully about God, as Kant himself often does, because reason must finally engage the mystery of being in the world and it must do this in accord with its overarching Transcendental Perspective. ${ }^{18}$

\section{From Kant to Otto to Tillich}

What we see from the foregoing analysis is that Palmquist's interpretation of Kant is strikingly consistent with Otto's thought. Palmquist highlights this consistency in a 1989 article entitled "Kant's Critique of Mysticism." He writes, "Rudolf Otto expounds in more

17 Palmquist, Kant's System of Perspectives, 58.

18 For Palmquist (Kant's Critical Religion, 313), "[Kant] not only believed in the reality of a transcendent God represented by our theoretical idea, manifested in our practical reason (speaking to our conscience), and communing with us in prayer, but also actively experienced this reality in his daily life." On the distinction between the overarching (thus, capitalized) Transcendental Perspective that governs all three Critiques and the specific (thus, uncapitalized) transcendental perspective operative within each Critique, see Palmquist's Kant's System of Perspectives (Lanham, MD: University of America Press, 1993), II.4. 
detail the implications of [Kant's] view of religious feeling in [The Idea of the Holy].... [I]n fact they are almost entirely consistent.... Once the perspectival character of Kant's thinking is taken into account, it becomes clear that he would have no trouble accepting such an explanation of his deepest experiences. 'Reason' is, for Kant, the ultimately unknowable mystery out of which arise all our human capacities for knowledge and goodness." 19 Like Palmquist's interpretation of Kant, Otto's philosophy of religion identifies three employments of reason-the scientific, the moral, and the aesthetic. More than this, Otto likewise contends that the most distinctive feature of any transcendental analysis of the possibility of religious experience is a kind of fourth employment of reason that is more ontologically robust than the others, dealing with the over-plus of meaning that eludes technical reason.

It should be noted that Otto is not strictly speaking a Kant exegete, but an innovator who extends Kant's critical philosophy to the religious dimension of human experience. This religious perspective or, as Otto refers to it, the "religious outlook" is the key link among the works of Palmquist, Otto, and Tillich. Although Tillich uses the term "ontological reason" to describe the point of contact between rea- son and reality, the way it functions in his system is very similar to Otto's "faculty of divination" or Palmquist's "Transcendental Perspective." For Tillich, "Neither structures, Gestalt processes, values, nor meanings can be grasped without ontological reason. Technical reason can reduce them to something less than their true reality." ${ }^{20}$ Technical reason (or reason in its three finite standpoints) can give a limited description of religion, but ontological reason enables us to grasp its true essence. All three of these thinkers - Palmquist, Otto, and Tillich - understand the religious dimension, outlook, or perspective not only as the natural fourth step for philosophy, but also as a particularly vital aspect of reason's overarching economy. ${ }^{21}$

19 Stephen R. Palmquist, "Kant's Critique of Mysticism: (2) The Critical Mysticism," Philosophy and Theology, vol. 4, 11, 83. Emphases mine.

20 Tillich, Systematic Theology, vol.1, 81.

${ }^{21}$ Otto remarks in a footnote, "constructing a 'humanity' prior to and apart from the most central and potent of human capacities is like nothing so much as the attempt to frame a standard idea of the human body after having previously cut off the head." Rudolf Otto, The Idea of the Holy (London: Oxford University Press, 1931), 37, f2. 
Ontological reason (or the Transcendental Perspective) serves as the primary link between philosophy and theology in both Palmquist's interpretation and Tillich's theology. Without a proper understanding of ontological reason, technical reason is corrupted and religion is reduced..$^{22}$ Internal to Tillich's understanding of ontology is a definite position on the relationship between philosophy and theology. Like Palmquist's interpretation of Kant, it has an hourglass-shaped structure. This hourglass integrates three principal aspects of reality-God, man, and world. Kant repeats over and again a similar three-fold structure in the Opus Posthumum as if he were proleptically groping his way toward Tillich: philosophy fundamentally works from the perspective of reason (logos) and the man-world relationship and theology fundamentally works from the perspective of faith in revelation (Logos, the Word of God) and the God-man relationship, with the method of correlation integrating them into a sys- tem. ${ }^{23}$

In conclusion, I have shown, through two of Tillich's lesser-known writings - the newspaper review articles on the person and work of Rudolf Otto - that Otto greatly influenced Tillich at a formative stage in his intellectual development and that several key elements of Tillich's mature thought are found in Tillich's analysis of Otto. I also have shown, in reference to the interpretations of Caird and Palmquist, that Otto's philosophy of religion can be fruitfully understood as a direct extension of Kant's critical philosophy. Furthermore, I have shown how the superstructure of Tillich's theology bears a striking resemblance to Kant's philosophy in the sense of Caird, Otto, and Palmquist. Tillich, in essence, formulates in theological terms a new and improved extension of Kant's philosophical program as it pertains to religion. The cumulative force of my argument supports the conclusions that Kant's philosophy through Otto has "constitutive significance" for Tillich's thought and, insofar as this analysis is accurate, Tillich's systematic theology is as much grounded on the philosophy of Kant as it is on the philosophy of Schelling.

22 Tillich, Systematic Theology, vol.1, 81. For Tillich, philosophy may sometimes function as though technical reason and ontological reason are not divided, but they are so divisible and theology itself must reject the confusion of this division. Tillich, Systematic Theology, vol.1, 82 .

${ }^{23}$ As Kant puts it in fragment form in the Opus Postumum, "Three principles: God, the world, and the concept of the subject which unites them and brings synthetic unity into these concepts (a priori) insofar as reason makes this transcendental unity itself' (21:23). 